\title{
Do water cuts affect productivity? Case study of African manufacturing firms
}

\author{
Busani Moyo* \\ Department of Economics, University of South Africa. PO Box 392, UNISA 0003, Pretoria
}

\begin{abstract}
This study sought to examine the impact of water disruptions on productivity in African manufacturing firms, using cross-sectional data from the World Bank enterprise surveys. We measured water infrastructure quality or water disruptions using the number of hours per day without water and found this indicator to be a negative and significant determinant of productivity. At country level, this variable seems to be a significant determinant in Uganda and Zambia, whilst firms in the food and agriculture, chemical and pharmacy as well as construction and metals sectors are also similarly affected. To improve economic growth through firm productivity and hence encourage employment creation and better standards of living, governments in Africa need to come up with measures to strengthen the effectiveness of both technical and institutional water infrastructure services.
\end{abstract}

Keywords: water cuts, productivity, African manufacturing

\section{Introduction}

According to the World Business Council for Sustainable Development (WBCSD) report (2005), water is not distributed evenly over the globe and fewer than 10 countries possess $60 \%$ of the world's available freshwater supply (Brazil, Russia, China, Canada, Indonesia, U.S., India, Columbia and the Democratic Republic of Congo). The report also argues that, after agriculture, industry is the second largest user of water, with about $22 \%$ of worldwide water being used in industries. Although the amount of water used varies widely from one type of industry to another, major industrial users include power plants, which use water for cooling or as a power source (i.e. hydroelectric plants), ore and oil refineries which use water in chemical processes, and manufacturing plants which use water as a solvent or for fabricating, processing, washing, diluting, cooling as well as for sanitation needs within the manufacturing facility (US Geological Survey, 2000). Industries that use large amounts of water normally produce such commodities as food, paper, chemicals, refined petroleum or primary metals. Many African countries are also manufacturers and exporters of these types of commodities. Adequate and sustainable provision of industrial water is therefore important for Africa to increase productivity and supply of goods as well as promote economic development. However, increasing demand, economic development and changes in climate (variable rainfall patterns/droughts) are posing serious challenges to sustainable water provision on the continent. Generally, the problem in Africa is mostly not about availability of water (there are abundant freshwater resources), but about accessibility (Tadese, 2009). This is a result of inadequate assessment, underdevelopment of water resources, lack of technical and institutional infrastructure as well as use of inappropriate water management systems (Tadese, 2009). According to UNEP

\footnotetext{
* To whom all correspondence should be addressed.

Im +2712 429 6191; fax: +2712 4293433 ;

e-mail: myxbus001@gmail.com or moyob@unisa.ac.za

Received 6 August 2010; accepted in revised form 30 May 2011.
}

(2004), most water utilities in many African countries are stateowned monopolies and thus low tariffs and fiscal constraints have resulted in little investment and poor maintenance of infrastructure in the water sector. Water cuts or water rationing as well as bursting water pipes remain common features in many of these African countries. (Many firms in Africa have tried to avoid this problem by drilling boreholes but this alternative increases fixed costs and may contribute to loss of competitiveness). Development policy experts have argued that poor provision of water will not only affect economic development, but will also constrain the continent's ability to meet its Millennium Development Goals (MDGs).

World Bank enterprise survey statistics on infrastructure obstacles facing manufacturing firms (which also included water infrastructure) show that, using days without water per month, South Asia is the continent most seriously affected by water disruptions followed by Sub-Saharan Africa (SSA), but, on a given day, Latin America and SSA top the list with, on average, more hours endured by firms without water (see Table 1 below). Country level statistics also show that water problems are very common in Tanzania as firms go for about 8 days without water per month, for about 13 hours a day, compared with an average of 2 days and about 10 hours a day in Zambia and Mauritius. Water disruptions are experienced on average for about a day in the other 2 remaining countries, for an average of 3 hours in South Africa and 20 hours in Uganda (see Table 1). This pattern is also replicated when looking at the number of firms with boreholes in these countries. Statistics in Table 1 below show that about $60 \%$ of firms in Zambia own boreholes followed by $35 \%$ in Tanzania. South Africa is the only country in the sample with less than $10 \%$ firms recorded as owning a borehole or well. (The survey sample included; South Africa, Zambia, Tanzania, Uganda and Mauritius. These countries were selected on the basis of availability of data on variables of interest.) World Development Indicators (2009) statistics also show that freshwater withdrawals by industry are lower in Africa compared to other regions. This could partly reflect lack of development of Africa's industrial sector or inadequacies of mechanisms of withdrawing water in the continent. 


\begin{tabular}{|l|c|c|c|c|c|}
\hline \multicolumn{7}{|c|}{ Table 1 } \\
\hline Country & $\begin{array}{c}\text { Days without water } \\
\text { per month }\end{array}$ & $\begin{array}{c}\text { Hours without } \\
\text { water per day }\end{array}$ & $\begin{array}{c}\text { Delay in obtaining } \\
\text { a water connection }\end{array}$ & $\begin{array}{c}\text { Percentage of firms } \\
\text { with a borehole/well }\end{array}$ & $\begin{array}{c}\text { Industry freshwater } \\
\text { withdrawals } \\
\text { (\% of total) }\end{array}$ \\
\hline South Africa & 0.42 & 3.42 & 13.90 & 2.05 & 6.0499 \\
\hline Zambia & 2.08 & 9.75 & 27.17 & 59.90 & 7.4713 \\
\hline Tanzania & 8.74 & 13.23 & 19.60 & 34.70 & 0.4823 \\
\hline Uganda & 0.51 & 20.82 & 20.13 & 13.45 & 16.000 \\
\hline Mautitius & 2.06 & 11.35 & 30.04 & 13.37 & 2.7586 \\
\hline Sub Saharan Africa & 7.24 & 13.99 & 28.60 & - & 2.9367 \\
\hline East Asia \& Pacific & 1.64 & 7.18 & 26.60 & - & 19.7393 \\
\hline Latin America & 3.97 & 16.02 & 34.11 & - & 10.3627 \\
\hline South Asia & 21.01 & 10.80 & 64.15 & - & 4.2065 \\
\hline Middle East North Africa & 6.28 & 10.86 & 62.23 & - & 6.18183 \\
\hline World & 6.43 & 13.06 & 34.94 & - & 20.1229 \\
\hline
\end{tabular}

Source:World Bank enterprise surveys; WDI, (2009); * These statistics are for 2007

The main aim of this study was therefore to investigate the impact of water infrastructure quality, i.e., water cuts, on productivity in African manufacturing firms. This is because water plays a very important role in enhancing the productivity of other input factors such as labour and capital. The assumption was that problems of water in Africa, though affected by poor rainfall patterns and increasing demand (due to population growth and economic development), are mostly a result of poor institutional and physical water infrastructure. Thus, inadequate assessment, underdevelopment of water resources, and use of inappropriate water management systems are all closely related to poor institutional and physical infrastructure. We also argue that the contributions of water infrastructure to productivity derive not from the mere existence or creation of the physical facilities like water treatment plants and water reservoirs, but from their operation and the value of the services generated. Thus water infrastructure reliability is more important than its availability. We therefore control for water reliability in this study by using the number of days or hours without water and ownership of boreholes, whilst at the same time highlighting the importance of other firm-specific factors. Thus water infrastructure is of little use to production if it is not reliable and that is why we expect water infrastructure reliability (how often firms go without water a day) to be more important than availability (annual freshwater withdrawals per capita or per industry).

The other problem with country-level indicators (annual freshwater withdrawals per capita or per industry) is that they assume that the quality of water infrastructure is the same across locations within a country, when in fact there may be interesting variations based on local governance (Dollar et al., 2005). Moreover, econometric modelling of the macro-level determinants of productivity also suffers from endogeneity problems. This could be because measures of infrastructural quality like water may be subject to 'halo effects', meaning that countries may have good water infrastructure and hence high water withdrawals because they are rich (Dollar and Kray, 2002). Thus high productivity may increase growth which may consequently also lead to an improvement in the quality of water infrastructure and amount of water withdrawals in a country. By shifting attention to firm-level analysis, we may possibly reduce this kind of bias, as firms can be assumed to take water infrastructural settings as given. In addition to water-related indicators, we also incorporate other firm characteristics that may affect productivity, such as firm size, firm age, foreign ownership and whether the firm owns a borehole or not. The other motivation for this research is that studies that explore the relationship between water infrastructure and productivity in Africa, particularly at firm level, are very scarce and, according to Estache (2005), this could be due to much econometric focus on human capital and low quality of available data.

This report is organised as follows: a review of some empirical studies on productivity and infrastructure (including water infrastructure), followed by a discussion of the methodological framework, data and variable measurement. The final sections present the findings and conclusions of the study.

\section{Empirical investigations of infrastructure impacts on productivity}

Empirical investigations of infrastructure impacts on productivity have been done by a number of researchers (e,g., Aschauer, 1989a; Munnell, 1990; Escribiano et al., 2009; Hulten, 1996). Aschauer (1989) studied the relationship between aggregate productivity and stock and flow of government spending variables in the US economy for the period 1949-85. In his estimations, using a general Cobb-Douglas production function, he treated government spending on public capital as one of the inputs in the production function and as proxy for infrastructure variables like water, electricity and transport. His results suggest that there is a strong positive relationship between output per unit of capital input, the private labour to capital ratio and the ratio of the public capital stock to the private capital stock. Mas et al. (1996) report on the regional dimension and temporal dimension of the impact of public capital on productivity gains. Using data for Spanish regions over the period 1964-91, they estimate a Cobb-Douglas production function by means of panel data techniques to control for unobserved state-specific characteristics. They found that economic infrastructure has a significant positive effect on productivity, but social infrastructure does not. However, the problem with using composite indicators is that it becomes difficult to disentangle the productivity impact of a specific infrastructure indicator like water.

Evidence presented by Aschauer (1989) and Munnell (1990) for the United States shows strong time-series and cross-state correlations between public infrastructure and productivity. However, Hulten and Schwab (1991) and Holtz-Eakin (1994) argued that these results disappear when time-series data is 
first differenced or when fixed effects are introduced in panel data regressions, suggesting that they were due to spurious correlations between non-stationary variables and endogeneity or misspecification (in the cross-section analysis). Cross-country evidence by Calderon and Serven (2003) showed that a substantial part of the growth in the output gaps between East Asia and Latin America can be traced back to the cutbacks in infrastructure spending that occurred in Latin America as a result of the debt crisis that was induced by fiscal adjustment programmes.

For Africa, Estache et al. (2005) made one of the first attempts to conduct a more systematic, quantitative assessment of the importance of Sub-Saharan Africa's infrastructure. They found that water, electricity, roads and telecommunications are crucial factors in promoting growth. Esfahani and Ramirez (2003) estimated that Sub-Saharan Africa's poor growth performance is in part related to under-investments in electricity, water and telecommunications infrastructure. Estache (2005) also estimates that if Africa had enjoyed Korea's quantity and quality of infrastructure, it would have raised its annual growth in per capita income by about $1 \%$. Hulten (1996) found that differences in the effective use of infrastructure resources explain one quarter of the growth differential between Africa and East Asia, and more than $40 \%$ of the growth differential between low and high growth countries.

According to Escribiano et al. (2009), empirical explorations of infrastructure effects on growth and productivity have generally been characterised by ambiguous results with little robustness. They argued that endogeneity of infrastructure measures have been the reason behind these contradictory findings. This endogeneity comes from measurement errors stemming from the use of public capital figures as proxies for infrastructure; omitted variables which arise when there is an unobserved third variable that affects the infrastructure and growth measure; under simultaneity, the bias and inconsistency of standard estimators follow in cases where infrastructure provision itself positively responds to productivity gains. They argued that these feedback effects would arise when there is an increase in reliance on the private sector for provision of infrastructure services. Escribiano and co-workers (2009) study on 26 African countries showed that poor quality of electricity, transport services and water provision affects allocative efficiency of slower growing countries. This study is an extension of their study in that it goes further to look at the impact of water disruptions on different sectors in the manufacturing industry. This will not only identify the country where water cuts are a serious obstacle to productivity but even the products that are heavily affected as a result.

\section{Methodology}

There are a number of methodologies that can be used to estimate productivity, each with its own strengths and weaknesses. One can use index numbers, parametric and non-parametric methods, data envelope analysis and stochastic frontiers. According to Biesebroeck (2003), index numbers and data envelopment analyses are flexible in the specification of technology, but do not allow for measurement errors in the data. He argued that parametric methods which calculate productivity from an estimated production function are less vulnerable to measurement errors, certainly in the dependent variable, but misspecification of the production function might be an issue.

However, for our study we proposed to use an empirical model that borrows from the works of Harris and Trainor (2005) and Njikam et al. (2005). We measured plant-level total factor productivity (TFP) using a standard Cobb Douglas production function as follows:

$$
Y_{i}=\alpha_{0}+\alpha_{1} L_{i}+\alpha_{2} M_{i}+\alpha_{3} K_{i}+\varepsilon_{i}
$$

where:

$Y$ refers to the $\log$ of output of firm $i$

$K$ is stock of capital

$M$ is material inputs

$L$ is number of workers in each firm

In order to calculate total factor productivity (TFP), the common approach is to obtain estimates of the elasticities of output with respect to inputs $\left(\alpha_{0}, \alpha_{1}, \alpha_{2}\right)$ and then to treat TFP as residuals from Eq. (1). Thus we obtain TFP as

$$
\operatorname{LnTFP} \equiv Y-\alpha_{1} L_{i}-\alpha_{2} M_{i}-\alpha_{3} K_{i}=\varepsilon_{i}
$$

Using this method, the TFP estimates from Eq. (2) would need to be regressed using a second-stage model against a set of determinants, such as the quality of power infrastructure variables, which do not feature when estimating Eq. (1) and yet which clearly are not random even though they are captured in the random error term $\varepsilon_{i}$, where $\varepsilon_{i} \sim$ n.i.d $\left(0 \sigma^{2}\right)$ is required for efficient and unbiased estimation of the model.

Newey and McFadden (1999) and Wang and Schmidt (2002) argue that using LnTFP in Eq. (2) in a second-stage model results in inefficient estimates (in the form of inconsistent standard errors and hence inconsistent $t$-values) of the determinants of TFP. Thus, Wang and Schmidt (2002) argue that this approach results in potentially-biased estimates, since by omitting factors from Eq. (1) that determine output, the estimates of the estimated elasticities will suffer from an omitted variable problem and thus LnTFP will be incorrectly measured. In addition, 2-stage approaches are inefficient because they ignore any cross-equation restrictions, since they do not take account of the correlation of the error terms across equations (Harris and Trainor, 2005).

Moreover, a more serious problem associated with this approach is that of omitted variable bias. Thus in the first-step regression, Eq. (1) ignores other known determinants of output and standard econometric theory predicts that estimated elasticities from Eq. (1) will be biased as a result. Thus the estimates obtained in the second-step regression will also be biased and this is true regardless of whether factor inputs and those variables that determine TFP are correlated or not. (In this case, the set of factors that determine output and those that determine TFP are firm-specific and therefore correlated.) Wang and Schmidt (2002) show that in the case of 2-step estimators of technical efficiency using a stochastic frontier production approach, simulations indicate that the bias due to the omitted variable problem is substantial. Our argument is that their results are relevant even when using 2-step estimations of the determinants of TFP using the technique shown by Eqs. (1) and (2).

The preferred approach therefore, is to directly include the determinants of output and thus TFP into Eq. (1), since this will avoid any problems of inefficiency and bias and will help in directly testing whether such determinants are statistically significant. Since TFP is defined as any change in output that is not due to changes in factor inputs, we include these determinants directly in Eq. (1) as follows:

$$
Y_{i}=\alpha_{0}+\alpha_{1} L_{i}+\alpha_{2} M_{i}+\alpha_{3} K_{i}+\beta_{1} \text { IINFRA }_{i}+\beta_{2} X_{i}+\varepsilon_{i}
$$


where:

WINFR $A_{i}$ is a measure of the quality of water infrastructure (water cuts)

$X_{i}$ is a vector of variables that includes all other productivity variables, such as firm age, firm size, dummy for foreign ownership, country and sectoral dummies.

We include these variables because some studies have shown that productivity is also affected by the size of the firm (Biesebroeck, 2005; Leung et al., 2008; Van Ark and Monnikhorf, 1996) and the age of the firm, as well as foreign ownership (de Kok et al., 2006; Huergo and Jaumandreu, 2004; Power, 1998; Griffith et al., 2004; Harris and Robinson, 2004). We include borehole or well ownership to ascertain whether such ownership minimises the negative effects of water cuts on productivity. This effect is captured by using the product of the borehole ownership dummy and quality of water infrastructure variables.

\section{Data and variable measurement}

The World Bank's Investment Climate Surveys (ICS) of manufacturing sectors from 5 Sub-Saharan African countries, namely, South Africa, Zambia, Uganda, Mauritius and Tanzania, are the primary source of the data used in this study. The surveys in these respective countries were done between the years 2002 and 2005. These firms were also drawn from 6 International Standards Industrial Classification (ISI) industries in 28 towns and cities and the selection of countries was based primarily on availability of comparable data on variables of interest.

Although the number of African countries covered by the study is rather small, between them, the 5 countries reflect the diversity of economies in the Sub-Saharan African region in terms of the level of economic development, export orientation and quality of infrastructure. Thus we have landlocked groups, low- and middle-income as well as large and small economies.

In order to convert some of our input and output values into common currency for estimation purposes, an average real effective exchange rate was used for the years in which the surveys were done in each of the study countries. This data is from the World Bank's World Development Indicators. Firm size was measured as the total number of permanent employees in each firm whilst firm age was calculated as the difference between the year in which the firm was established and the year in which the survey was done. Foreign ownership is a dummy, taking the value of 1 if the firm has at least $10 \%$ foreign ownership and zero otherwise. Water infrastructure quality is measured using the number of days firms go without water per month, and the number of hours without water per day. Since data on the number of days without water were elicited on an annual basis, we recalculated these outage days by dividing all firm responses by 12 in order to get water-cut days per month. To minimise the impact of non-responses on the size of our sample, we replaced missing water infrastructure quality observations with regional level averages. Thus we calculated the average number of hours or days that firms in a particular city or region go without water per day or month, respectively. In carrying out our estimations, we also expressed firm size, firm age, labour (measured as sum of permanent and temporary employees), raw materials, capital (measured using replacement cost of plant and machinery) in logarithm.

Dummies were also created to capture the unobserved country and sector heterogeneity. This is because some products may use less water than others whilst in some cases enterprises located in countries with good institutions and economic policies might be more productive than those from poorer institutional and policy settings. These dummies could also capture geographic characteristics of the countries and sectoral comparative advantage based on the countries' factor endowment differences (Yoshino, 2008). The manufacturing sectors covered include textile and garment; plastic, paper and packaging; construction and metal; chemical and pharmacy; wood and furniture; as well as food and agriculture. We did our estimations using ordinary least squares (OLS) and the crosssectional results are presented below.

\section{Results}

\begin{tabular}{|l|l|l|l|}
\hline \multicolumn{5}{|c|}{ Table 2 } \\
\hline & \multicolumn{1}{|c|}{ Summary of cross-country results } \\
\hline Sector dummies & Yes & (2) & (3) \\
\hline Country dummies & Yes & Yes & Yes \\
\hline Foreign ownership & 0.197 & 0.252 & Yes \\
& $(0.076)^{* * *}$ & $(0.091)^{*}$ & $(0.088)^{*}$ \\
\hline Firm age & 0.033 & 0.001 & 0.222 \\
& $(0.033)$ & $(0.042)$ & $(0.039)^{* *}$ \\
\hline Firm size & -0.024 & 0.207 & 0.012 \\
& $(0.024)$ & $(0.030)^{* *}$ & $(0.028)$ \\
\hline Water disruption & -0.036 & -0.045 & \\
(hours) & $(0.016)^{*}$ & $(0.003)^{* *}$ & \\
\hline Water disruption and & & 0.0002 & 0.075 \\
borehole interaction & & $(0.004)$ & $(0.016)^{* *}$ \\
\hline Water disruption & & & 0.029 \\
(days) & & & $(0.014)$ \\
\hline Log capital input & 0.056 & 0.075 & 0.077 \\
& $(0.018)^{* * *}$ & $(0.022)^{* * *}$ & $(0.022)^{* * *}$ \\
\hline Log material input & 0.425 & 0.509 & 0.507 \\
& $(0.018)^{* * *}$ & $(0.023)^{* * *}$ & $(0.022)^{* * *}$ \\
\hline Log Labour input & 0.264 & 0.181 & 0.189 \\
& $(0.024)^{* * *}$ & $(0.029)^{* * *}$ & $(0.028)^{* * *}$ \\
\hline Constant & 3.089 & 2.835 & 4.108 \\
& $(0.249)^{* * *}$ & $(0.287)^{* * *}$ & $(0.407)^{* * *}$ \\
\hline Observations & $\mathbf{7 3 0}$ & $\mathbf{7 3 0}$ & $\mathbf{7 3 5}$ \\
\hline
\end{tabular}

Absolute values of standard errors in parenthesis

**Significant at 5\% level; ***significant at 1\% level; *significant at $10 \%$ level

In carrying out the above estimations, we used different indicators of water infrastructure quality in order to check whether our estimations were robust in response to changes in variable specifications. The use of cross-sectional, country level and sectoral regressions is meant to identify the countries and sectors where water cuts or disruptions play a significant role in affecting productivity.

It is generally argued that firms with some foreign ownership are more productive than those without (Yoshino, 2008; Griffith et al, 2004; Harris and Robinson, 2004). This is because foreign ownership brings with it skills and technologies that help improve the productivity of firms (productivity effect). Results from the above regressions show that foreign ownership is a robust and significant determinant of productivity. At country level, this variable is positive and significant in Zambia, Tanzania and South Africa, as well as in the food and agricultural and chemical and pharmacy sectors. This is partly 


\begin{tabular}{|l|l|l|l|l|l|}
\hline \multicolumn{5}{|c|}{ Suble 3 } \\
\multicolumn{5}{|c|}{ Summary of country level results (using hours) } \\
\hline & $\begin{array}{l}\text { South } \\
\text { Africa }\end{array}$ & Zambia & Uganda & Mauritius & Tanzania \\
\hline Variables & Yes & Yes & Yes & Yes & Yes \\
\hline Sector dummies & 0.472 & 0.393 & 0.265 & 0.141 & 0.593 \\
\hline Foreign ownership & $(0.136)^{* *}$ & $(0.124)^{*}$ & $(0.186)$ & $(0.221)$ & $(0.257)^{* *}$ \\
\hline Firm age & 0.074 & -0.005 & 0.280 & 0.121 & 0.002 \\
& $(0.052)$ & $(0.057)$ & $(0.086)^{* *}$ & $(0.015)^{* *}$ & $(0.132)$ \\
\hline Firm size & 0.028 & 0.255 & 0.152 & -0.006 & -0.045 \\
& $(0.043)$ & $(0.052)^{* *}$ & $(0.051)^{* *}$ & $(0.061)^{* *}$ & $(0.097)$ \\
\hline Water disruption & -0.014 & -0.106 & -0.007 & -0.006 & 0.009 \\
& $(0.021)$ & $(0.021)^{* *}$ & $(0.004)^{* *}$ & $(0.010)$ & $(0.019)$ \\
\hline Water disruption and borehole & 0.054 & 0.217 & 0.026 & 0.012 & 0.016 \\
& $(0.066)$ & $(0.012)^{* * *}$ & $(0.005)^{* *}$ & $(0.015)$ & $(0.016)$ \\
\hline interaction & 0.022 & 0.098 & 0.025 & 0.048 & 0.135 \\
\hline Log capital input & $(0.031)$ & $(0.041)^{* *}$ & $(0.038)$ & $(0.044)$ & $(0.060)^{* *}$ \\
\hline Log material input & 0.329 & 0.495 & 0.453 & 0.498 & 0.558 \\
& $(0.029)^{* * *}$ & $(0.049)^{* * *}$ & $(0.040)^{* * *}$ & $(0.043)^{* * *}$ & $(0.064)^{* * *}$ \\
\hline Log Labour input & 0.359 & 0.202 & 0.284 & 0.093 & 0.127 \\
& $0.039)^{* * *}$ & $(0.067)^{* * *}$ & $(0.051)^{* * *}$ & $(0.050)^{*}$ & $(0.085)$ \\
\hline Constant & 3.931 & 2.459 & 4.722 & 6.420 & 3.225 \\
& $(0.605)^{* * *}$ & $(0.545)^{* * *}$ & $(0.065)^{* * *}$ & $(1.052)^{* * *}$ & $(1.231)^{* * *}$ \\
\hline Observations & $\mathbf{2 5 9}$ & $\mathbf{1 2 9}$ & $\mathbf{1 6 8}$ & $\mathbf{1 2 5}$ & $\mathbf{1 0 5}$ \\
\hline
\end{tabular}

**Significant at $5 \%$ level; $* * *$ significant at $1 \%$ level; * significant at $10 \%$ level

\begin{tabular}{|l|l|l|l|l|l|}
\hline \multicolumn{7}{|l|}{ Tummary of sector level results (using hours) } \\
\hline Variables & $\begin{array}{l}\text { Textile and } \\
\text { Garments }\end{array}$ & $\begin{array}{l}\text { Food and } \\
\text { Agriculture }\end{array}$ & $\begin{array}{l}\text { Chemical and } \\
\text { Pharmacy }\end{array}$ & $\begin{array}{l}\text { Construction } \\
\text { and Metal }\end{array}$ & $\begin{array}{l}\text { Plastic, Paper } \\
\text { and packaging }\end{array}$ \\
\hline Country dummies & Yes & Yes & Yes & Yes & Yes \\
\hline Foreign ownership & 0.014 & 0.254 & 0.561 & 0.418 & 0.382 \\
& $(0.238)$ & $(0.125)^{* *}$ & $(0.143)^{* *}$ & $(0.538)$ & $(0.379)$ \\
\hline Firm age & 0.087 & 0.033 & -0.343 & 0.208 & 0.153 \\
& $(0.117)$ & $(0.059)$ & $(0.032)$ & $(0.309)$ & $(0.151)$ \\
\hline Firm size & 0.026 & -0.025 & 0.257 & 0.305 & -0.142 \\
& $(0.072)^{* *}$ & $(0.0412)$ & $(0.096)^{* *}$ & $(0.108)^{* *}$ & $(0.125)$ \\
\hline Water disruption & -0.018 & -0.038 & -0.043 & -0.219 & 0.112 \\
& $(0.015)$ & $(0.003)^{* *}$ & $(0.014)^{*}$ & $(0.038)^{* *}$ & $(0.47)$ \\
\hline Water disruption and borehole & 0.006 & 0.006 & 0.016 & 0.117 & 0.025 \\
interaction & $(0.017)$ & $(0.005)$ & $(0.095)$ & $(0.040)^{* * *}$ & $(0.030)$ \\
\hline Log capital input & 0.096 & 0.017 & -0.008 & 0.228 & 0.141 \\
& $(0.047)^{* *}$ & $(0.033)$ & $(0.041)$ & $(0.123)^{*}$ & $(0.166)^{* * *}$ \\
\hline Log material input & 0.473 & 0.559 & 0.756 & 0.032 & 0.498 \\
& $(0.049)^{* * *}$ & $(0.034)^{* * *}$ & $(0.053)^{* * *}$ & $(0.159)$ & $(0.115)^{* * *}$ \\
\hline Log Labour input & 0.157 & 0.162 & 0.435 & 0.477 & 0.319 \\
& $(0.064)^{* *}$ & $(0.049)^{* * *}$ & $(0.068)$ & $(0.226)^{* *}$ & $(0.074)$ \\
\hline Constant & 3.394 & 5.421 & 2.468 & 3.921 & 3.785 \\
& $(0.769)^{* * *}$ & $(0.639)$ & $(0.976)$ & $(1.376)^{* * *}$ & $(1.550)^{* *}$ \\
\hline Observations & $\mathbf{1 3 0}$ & $\mathbf{2 4 9}$ & $\mathbf{1 2 0}$ & $\mathbf{1 0 0}$ & $\mathbf{9 8}$ \\
\hline
\end{tabular}

Absolute values of standard errors in parenthesis

**Significant at $5 \%$ level; ***significant at $1 \%$ level; * significant at $10 \%$ level

supported by descriptive statistics in that there are relatively more firms in Zambia and South Africa with foreign ownership and this could explain the presence of the productivity effect. These results also show that firm size has an expected positive effect though not consistently significant. The same pattern applies to the age variable. These results suggest that being older and large in size has a weak positive effect on a firm's level of productivity. This basically means that economies of scale and experience do have an influence on a firm's productivity. The pattern of impact of these 2 variables seems to be replicated even at country and sectoral level. The size variable is significant in Zambia and Uganda whilst the age variable is significant in Uganda and Mauritius. At sectoral level the size variable is significant in the textile and garment, chemical and pharmacy as well as construction and metal sectors. These results partly support Biesebroeck's (2005) finding 
that total factor productivity distributions of large and small African manufacturing firms are significantly different, even though his study does not indicate the extent to which large firms are more productive compared to small firms. In fact, Biesebroeck, (2005) argued that large firms grow more rapidly and improve productivity faster, conditional upon previous performance. Lee and Tang (2001) also found that large firms with between 100 and 500 employees are more productive than those with less than 100 workers. The size argument is that as the firm increases in size it is initially expected to have a positive effect on productivity due to economies of scale. However, when the firm grows beyond a certain size, diseconomies of scale may start to set in and thus negatively influence productivity. This could partly explain the negative nature of the size variable in Tanzania; it is likely that firms in this country have passed the threshold size level such that increases in firm size no longer bring about economies but diseconomies of scale. However, using cross-sectional data, it is difficult to test this argument. With regard to the age variable, Palangkaraya et al. (2007), using Australian data, found similar evidence (though somewhat weak) that older firms are less productive.

The variable that is of central interest in this study is that of water disruptions. Our argument is that water infrastructure is an intermediate input and its efficient supply raises the profitability of production and hence enhances the marginal productivity of labour and capital (Kessides, 1993). A large number of hours without water must therefore have a negative effect on productivity. The results reported above largely support this expectation. Thus, using the number of hours without water, water infrastructure quality has a negative and significant effect on productivity. However, when using the number of days per month without water, this variable becomes insignificant but still negative. The likely reason for this is that measuring water disruptions using the number of hours a day is more appropriate than using the number of days a month. This is true in that if 2 firms (Firm 1 and Firm 2) in different locations experience about 2 days of water shortages per month, but Firm 1 experiences more hours of water disruptions a day than Firm 2, then Firm 1 faces more severe water problems than Firm 2. Thus days without water may not be a better measure of the severity of water infrastructure problems than hours without water. At sectoral level, water infrastructure quality has a negative and significant effect in the food and agriculture, chemical and pharmacy as well as construction and metal sectors. This partly supports the argument that industries that use large amounts of water normally produce such commodities as food, paper, chemicals, refined petroleum or primary metals. There is, however, a weak negative effect on textiles and garments as well plastic, paper and packaging sector firms, suggesting that the production of these products does not require a large amount of water or that water problems are not severe in these sectors. At country level the variable is consistently negative, though significant only in Uganda and Zambia. This is partly supported by descriptive statistics. in that there are relatively more firms with boreholes in Zambia (60\%), suggesting that water problems may be severe in this country (see Table 1 above). We used the product of water infrastructure quality variable and the borehole ownership dummy to ascertain whether owning a borehole or well helps in minimising the negative impact of poor water infrastructure. Results show that boreholes partly ameliorate water problems. This variable is consistently positive but significant only when using the number of days without water and this is true for the construction and metal sector as well as for Zambian firms. Thus about $60 \%$ of firms in Zambia own a borehole or well.

\section{Conclusions}

The primary objective of this study was to examine the role played by the quality of water infrastructure on firm productivity in the manufacturing sector in Africa. The significance of water disruptions as a variable affecting productivity suggests that water is important in fostering economic growth and there is a need therefore for governments in Africa to come up with water infrastructure development plans so as to minimise the occurrence of water cuts. This could be done by improving water assessments, development of water resources, as well as use of appropriate water management systems. Development and maintenance of quality water infrastructure (both physical and institutional) is central in achieving these objectives. This could also be achieved through the commonly-used private-public partnership arrangements or privatisation or commercialisation of staterun water utility companies. Proper regulatory mechanisms can be used to minimise abuse of monopoly power by these privatised utility companies. In so doing, resources will be generated to build and maintain quality water infrastructure facilities which will not only support the productivity and growth of firms, but even result in the generation of employment and increases in income growth. The significance of the water-borehole interaction variable also means that firms in countries with serious water problems should be encouraged or assisted in acquiring alternative water sources like boreholes as this appears to partly support the productivity of firms.

\section{References}

ASCHAUER D (1989) Is public expenditure productive? J. Monetary Econ. 23 177-200.

ASIEDU E (2002) On the determinants of FDI in developing countries. Is Africa different? World Dev. 30 (1) 107-118.

BIESEBROECK JV (2005) Firm size matters: Growth and productivity growth in African manufacturing. J. Econ. Dev. Cult. Change 53 (3) 545-583.

BIESEBROECK JV (2003b) Exporting raises productivity in Sub Saharan African manufacturing firms. J. Int. Econ. 67 373-391. BIESEBROECK JV (2003a) Revisiting some productivity Debates. NBER Working paper Series No. 10065.National Bureau of Economic Research, Cambridge USA

CALDERON C and SERVEN L (2003) The output cost of Latin America's infrastructure gap. Central Bank of Chile Working Paper No. 186. Central Bank of Chile, Chile.

DAVID P (1990) The Dyanamo and the Computer: A historical perspective on the productivity paradox. Am. Econ. Rev. 80 355-361.

DEVINE W (1983) From shafts to wires: Historical perspective on electrification. J. Econ. Hist. 2 347-372.

DOLLAR D and KRAY A (2003) Institutions, trade and growth. J. Monetary Econ. 50 (1) 133-162.

DE KOK JMP, FRIS P and BROUWER P (2006) On the relationship between firm age and productivity growth. EIM Business and Policy Research Series No. H200617. Scales Research reports: Zoetermeer, The Netherlands.

ECONOMIC COMMISSION FOR AFRICA (2001) United Nations Report: Defining Priorities for Regional Integration through Infrastructure Development.

ESCRIBIANO A, GUASCH L and PENA J (2009b) Assessing the impact of Infrastructure quality on firm productivity in Africa. Cross country comparisons based on Investment Climate surveys. Policy Research Working Paper Series No 5191, World Bank. 
ESCRIBIANO A, GAUSCH J, DE ORTE and PENA J (2009a) Investments Climate assessments in Indonesia, Malaysia, Philippines and Thailand. Results from pooling firm level data. Singapore Econ. Rev. 54 (3) 335-366.

ESFAHANI H and RAMIREZ MT (2003) Institutions, infrastructure and economic growth. J. Dev. Econ. 70 443-477.

ESTACHE A (2005b) What do we know about Sub Saharan Africa's infrastructure and the impact of its 1990 Reforms? Mimeo, World Bank, Washington DC.

ESTACHE A and GOICOECHEA A (2005a) A research data base on Infrastructure Economic performance. World Bank Policy Research Working Paper No. WPS3643. World Bank.

GRIFFITH R, REDDING S and SIMPSON H (2004): Foreign ownership and productivity: New evidence from the services sector and the R\&D lab. Center for Economic Performance (CEP) Discussion Paper No. 649. London School of Economics and Political Science, United Kingdom.

HARRIS R and TRAINOR M (2005) Capital subsidies and their impact on total factor productivity: Firm level evidence from Northern Ireland. J. Reg. Sci. 45 (1) 49-74.

HARRIS R and ROBINSON C (2003) Foreign ownership and productivity in the United Kingdom. Estimates for UK Manufacturing using the ARD. Rev. Ind. Organ. 22 207-223.

HOLTZ-EAKIN D (1994) Public sector capital and the productivity puzzle. Rev. Econ. Stat. 76 12-21.

HUERGO E and JAMANDREU J (2004) Firm age, process innovation and productivity growth. Int. J. Ind. Organ. 22 (4) 541-559.

HULTEN C (1996) Infrastructure, capital and economic growth. How well you use it may be more important than how much you have. NBER Working Paper Series No. 5847. National Bureau of Economic Research, Cambridge USA.

KESSIDES C (1993) Contributions of infrastructure to economic development. A review of experience and policy implications. World Bank Discussion Paper No. 213. World Bank.

LEE F and J TANG (2001): Multifactor productivity disparity between Canadian and US manufacturing firms. J. Prod. Anal. 15 115-128.

MAS M, MAUDOS J, PREZ F and URIEL E (1996) Infrastructure and productivity in the Spanish regions. Reg. Stud. 7 (30) 641-649.

MUNNELL A (1990) Why has productivity growth declined? Productivity and public investment. New Engl. Econ. Rev. 1990 (Jan/Feb) 3-22
NEWY W K and McFADDEN D (1999) Large sample estimation and hypothesis testing. In: McFadden D and Engle R (eds.) Handbook of Econometrics Vol 4. North Holland, Amsterdam. 2113-2245.

NIKAM O, BINAM N J and TACHI S (2006) Understanding total factor productivity growth in SSA. Working Paper Series No. 2006/3. Secretariat for Institutional Support for Economic Research in Africa (SISERA) Dakar, Senegal.

OSHIKOYA T and HUSSAIN N (2001) Infrastructure for economic development in Africain OECD (2002): Development Centre Seminars: Regional Integration in Africa. Proc. 2nd Forum on African Perspective, ADB-OECD, Paris, France.

PALANGKARAYA A, STIERWALD A and YONG J (2009) Is firm productivity related to size and age? The case of large Australian firms. J. Ind. Competition Trade 9 (2) 167-195.

TADESE D (2009) Climate change and transboundary water resource conflicts in Africa. Institute for Security Studies Report Institute for Security Studies, Pretoria, South Africa.

UNEP (United Nations Environment Programme) (2004): Annual Report 2009 - Protecting the earth's resources. UNEP. URL: http:// www.unep.org/AnnualReport/2004/01\%20AR\%20LAYOUT\%20 PART\%202.pdf (Accessed 3 July 2011

UNITED STATES GEOLOGICAL SURVEY (2005) URL: http:// ga.water.usgs.gov/edu/wuin.html (Accessed 3 July 2011).

VAN ARK B and MONNIKHOF E (1996) Size distribution of output and employment: A data set for manufacturing industries in five OECD countries 1960s-1990. Organisation of Economic Cooperation and Development (OECD), Economics Department Working Paper No. 166. OECD Publishing, France.

WANG H and SCHMIDT (2002) One step and two step estimations of the effects of exogenous variables on technical efficiency levels. J. Prod. Anal. 18 129-144.

WORLD BUSINESS COUNCIL FOR SUSTAINABLE DEVELOPMENT (WBCSD) REPORT (2005) Water Facts and Trends. WBCSD Publications, Geneva, Switzerland.

WORLD DEVELOPMENT INDICATORS (2009) Data and Statistics. World Bank Publications Washington DC, USA.

YOSHINO Y (2008) Domestic constraints, firm characteristics and geographical diversification of firm level manufacturing exports in Africa. World Bank Policy Research Working paper No. 4575. World Bank.

\section{Appendix - See next page}




\section{Appendix}

Table 5

Summary of descriptive statistics

\begin{tabular}{|c|c|c|c|c|c|c|}
\hline & $\begin{array}{c}\text { Number of } \\
\text { firms }\end{array}$ & $\begin{array}{l}\text { \% foreign } \\
\text { equity }\end{array}$ & $\begin{array}{c}\text { Own } \\
\text { borehole (\%) }\end{array}$ & $\begin{array}{c}\text { Foreign } \\
\text { invested (\%) }\end{array}$ & $\begin{array}{l}\text { Firm age } \\
\text { (average) }\end{array}$ & $\begin{array}{l}\text { Firm size } \\
\text { (average) }\end{array}$ \\
\hline \begin{tabular}{|l|} 
Countries \\
South Africa (2003) \\
Tanzania (2003) \\
Uganda (2003) \\
Zambia (2002) \\
Mauritius (2005)
\end{tabular} & $\begin{array}{l}603 \\
276 \\
300 \\
207 \\
212\end{array}$ & $\begin{array}{c}15.13 \\
15.77 \\
20.74 \\
24.37 \\
8.90\end{array}$ & $\begin{array}{l}2.05 \\
34.70 \\
13.45 \\
59.90 \\
13.37\end{array}$ & $\begin{array}{l}19.57 \\
23.19 \\
23.00 \\
29.47 \\
16.11\end{array}$ & $\begin{array}{l}25 \\
18 \\
13 \\
19 \\
24\end{array}$ & $\begin{array}{c}344 \\
96 \\
75 \\
225 \\
170\end{array}$ \\
\hline $\begin{array}{l}\text { Sectors } \\
\text { Textile and Garments } \\
\text { Food and agric } \\
\text { Chemical pharmacy } \\
\text { Plapackaging } \\
\text { Wood and furniture } \\
\text { Construction and metal }\end{array}$ & $\begin{array}{l}180 \\
395 \\
138 \\
193 \\
111 \\
139\end{array}$ & $\begin{array}{c}11.43 \\
20.94 \\
23.94 \\
14.12 \\
6.49 \\
15.82\end{array}$ & $\begin{array}{l}21.26 \\
42.68 \\
40.96 \\
20.21 \\
18.82 \\
28.71\end{array}$ & $\begin{array}{c}16.67 \\
25.32 \\
29.71 \\
17.10 \\
9.01 \\
20.86\end{array}$ & $\begin{array}{l}21 \\
19 \\
20 \\
20 \\
18 \\
23\end{array}$ & $\begin{array}{l}326 \\
265 \\
124 \\
109 \\
108 \\
103\end{array}$ \\
\hline $\begin{array}{l}\text { Firm characteristics } \\
\text { Own generator } \\
\text { Foreign ownership } \\
\text { Internet }\end{array}$ & $\begin{array}{l}475 \\
347 \\
900\end{array}$ & $\begin{array}{l}26.27 \\
79.81 \\
22.44\end{array}$ & $\begin{array}{l}45.76 \\
43.12 \\
29.55\end{array}$ & $\begin{array}{l}33.89 \\
28.33 \\
16.11\end{array}$ & $\begin{array}{l}23 \\
22 \\
24\end{array}$ & $\begin{array}{l}346 \\
419 \\
313\end{array}$ \\
\hline $\begin{array}{l}\text { Firm sizes } \\
\text { Micro } \\
\text { Small } \\
\text { Medium } \\
\text { Large }\end{array}$ & $\begin{array}{l}171 \\
546 \\
320 \\
561\end{array}$ & $\begin{array}{c}8.65 \\
10.87 \\
15.66 \\
26.49\end{array}$ & $\begin{array}{c}7.10 \\
19.94 \\
37.58 \\
54.88\end{array}$ & $\begin{array}{l}10.19 \\
14.53 \\
19.68 \\
34.31\end{array}$ & $\begin{array}{l}11 \\
15 \\
21 \\
30\end{array}$ & $\begin{array}{c}4.7 \\
25 \\
71 \\
589\end{array}$ \\
\hline
\end{tabular}

Source: Author's own calculations based on World Bank's Investment Climate Surveys

Micro $=$ firm size $<10 ;$ Small $=$ firm size $<50$ and $\geq 10 ;$ Medium $=$ firm size $<100$ and $\geq 50 ;$ Large $=$ firm size $\geq 100$ 